\title{
Expression and prognostic value of estrogen receptor $\beta$ in patients with triple-negative and triple-positive breast cancer
}

\author{
LIYING GUO ${ }^{1}$, QIANWEN ZHU ${ }^{2}$, MULATI AISIMUTUOLA ${ }^{1}$, DILIMINA YILAMU ${ }^{1}$, \\ SHA LIU $^{1}$ and ADINA JAKULIN ${ }^{1}$ \\ ${ }^{1}$ Department of Breast Cancer, Digestive and Vascular Center, First Affiliated Hospital of Xinjiang Medical University, \\ Ürümqi, Xinjiang 830054; ${ }^{2}$ Department of General Surgery, Affiliated Hospital of Taishan Medical University, \\ Tai'an, Shandong 271000, P.R. China
}

Received August 21, 2014; Accepted February 24, 2015

DOI: $10.3892 / \mathrm{etm} .2015 .2380$

\begin{abstract}
The aim of the present study was to investigate the expression of estrogen receptor $\beta$ (ER $\beta$ ) in triple-negative and triple-positive breast cancer patients, and evaluate its utility as a prognostic factor. Between January 2000 and December 2010, primary tumor tissue samples were collected from 234 subjects, including 107 triple-negative and 127 triple-positive breast cancer patients. The samples were embedded in paraffin and immunohistochemical staining was conducted to determine the expression levels of ER $\beta$. The Kaplan-Meier method was used to analyze patient survival rates. ER $\beta$ expression was observed in 38/107 patients $(35.5 \%)$ with triple-negative breast cancer and $63 / 127$ patients $(49.6 \%)$ with triple-positive breast cancer. The ER $\beta$ expression rate was significantly decreased in the patients with triple-negative breast cancer, as compared with those with triple-positive breast cancer $(\mathrm{P}=0.03)$. Analysis of the survival rates indicated that patients with triple-negative breast cancer and positive ER $\beta$ expression exhibited poor disease progression-free survival (DFS) compared with those with negative $E R \beta$ expression ( $\mathrm{P}=0.021)$. However, no statistically significant difference was observed in the DFS between the triple-positive breast cancer patients with positive and negative ER $\beta$ expression. Therefore, the expression of ER $\beta$ varies between triple-negative and triple-positive breast cancer patients. In addition, positive expression of ER $\beta$ indicates a poor prognosis in triple-negative breast cancer patients; however, this is not the case for triple-positive breast cancer patients.
\end{abstract}

Correspondence to: Dr Liying Guo, Department of Breast Cancer, Digestive and Vascular Center, First Affiliated Hospital of Xinjiang Medical University, 137 Liyushan Road, Ürümqi, Xinjiang 830054, P.R. China

E-mail: gejsy318@126.com

Key words: estrogen receptor $\beta$, triple-negative breast cancer, prognosis

\section{Introduction}

Triple-negative breast cancer is a subtype of the disease, in which estrogen receptor (ER), progesterone receptor (PR) and human epidermal growth factor receptor-2 (Her-2) are not expressed. Triple-negative breast cancer accounts for 10-17\% of total breast cancer cases (1). This form of breast cancer is highly invasive and is associated with a short survival time and poor patient prognosis (1). Conversely, triple-positive breast cancer tissue expresses ER, PR and Her-2. Traditionally, breast cancer ER refers to the estrogen receptor $\alpha(E R \alpha)$, which is the most important subtype of the ER. Traditional endocrine therapy is targeted primarily against $\mathrm{ER} \alpha$ and PR; however, only $40-70 \%$ of breast tissue expresses ER $\alpha(2,3)$. In 1996, Kuiper et al observed that the estrogen receptor subtype, estrogen receptor $\beta$ (ER $\beta)$ was present in breast cancer cells (4). Numerous studies (5-7), including in vitro cell cultures, animal models and immunohistochemical studies, have indicated that ER $\beta$ is closely associated with breast cancer cell proliferation and invasion. Thus, it may be possible to develop novel therapeutic approaches for triple-negative breast cancer that traditionally do not respond to endocrine therapy. Furthermore, previous studies have indicated that ER $\alpha$ and ER $\beta$ expression levels vary among different forms of breast cancer $(8,9)$. Patients with negative ER $\alpha$ expression also exhibit positive ER $\beta$ expression (10).

In the present study, the expression levels of ER $\beta$ were detected in 107 patients with triple-negative breast cancer and 127 patients with triple-positive breast cancer in order to determine the association between ER $\beta$ expression and the prognosis of patients with triple-negative and triple-positive breast cancer. In addition, the effect of ER $\beta$ expression on the survival rates of breast cancer patients was analyzed.

\section{Materials and methods}

Clinical data. Primary cancer tissue samples were collected from 107 patients with triple-negative breast cancer and 127 patients with triple-positive breast cancer, who had been hospitalized at the First Affiliated Hospital of Xinjiang Medical University (Ürümqi, China) between January 2000 and December 2010. The tissue samples were paraffin-embedded, 
and complete follow-up data of the patients were available. All the patients received standard comprehensive cancer treatment, which included surgery, anthracycline/taxane-based chemotherapy and radiotherapy. Patient follow-up was conducted for 2-12 years, with a median follow-up period of 3.5 years. During the follow-up period, nine patients exhibited cancer recurrence and metastasis, while 26 patients succumbed to the disease. All patients were female, with an age range of 32-72 years and a median age of 49 years. Clinical data were obtained via telephone or from the medical records of patients who were regularly admitted to the hospital for review. The disease progression-free survival (DFS) of the patients was defined as the period between the date of cancer diagnosis to the first occurrence of metastasis or cancer-associated mortality. During the follow-up period, 10 patients with triple-negative breast cancer and 14 patients with triple-positive breast cancer were excluded. These patients had succumbed to causes other than breast cancer, or had been lost to follow-up at the time of last contact or prior to the study cut-off point.

Prior written and informed consent was obtained from each patient, and the study was approved by the Ethics Review Board of Xinjiang Medical University (Ürümqi, China).

Immunohistochemical analysis. Breast cancer tissue specimens were fixed in $10 \%$ formaldehyde for $24 \mathrm{~h}$, embedded in paraffin, sliced into $3-\mu \mathrm{m}$ sections and incubated overnight at $70^{\circ} \mathrm{C}$. The sections were subsequently dewaxed in xylene for $20 \mathrm{~min}$ and rehydrated in graded alcohols. Endogenous peroxidase activity was blocked with $3 \%$ hydrogen peroxide for $10 \mathrm{~min}$. For antigen retrieval, the sections were boiled in EDTA antigen retrieval solution for $20 \mathrm{~min}$. After cooling to room temperature and washing with phosphate-buffered saline (PBS), the sections were incubated with a polyclonal rabbit anti-human ER $\beta$ primary antibody (\#BY-02101; Shanghai Yueyan Biological Technology, Co., Ltd., Shanghai, China) at $37^{\circ} \mathrm{C}$ for $1 \mathrm{~h}$ in the dark. Subsequently, the sections were incubated with a horseradish peroxidase-conjugated anti-rabbit IgG secondary antibody (Shanghai Gene Biological Technology Co., Ltd., Shanghai, China) at $37^{\circ} \mathrm{C}$ for $30 \mathrm{~min}$ in the dark. Following incubation with the antibodies, the sections were developed with 3,3'-diaminobenzidine chromogenic reagent (Tianjin East Tengen Fine Chemical Reagent, Tianjin, China) for $5 \mathrm{~min}$ and counterstained with hematoxylin. Following hydrochloric acid differentiation and dehydration in graded alcohols, the sections were mounted with neutral gum (Tianjin East Tengen Fine Chemical Reagent). Positive samples were used as the positive controls, while for the negative control, the secondary antibody was replaced with PBS.

Immunohistochemical staining results were evaluated by an experienced pathologist. Cells that exhibited brown staining were considered to be ER $\beta$-positive. Five fields were randomly selected and observed under high magnification (DM LB2; Leica Camera AG, Wetzlar, Germany). The ER $\beta$ expression rate was defined as the ratio of the number of $\operatorname{ER} \beta$ positive cells to the total number of cells in each field. An ER $\beta$ rate $<1 \%$ was defined as $\operatorname{ER} \beta$ negative $[\operatorname{ER} \beta(-)]$ and an $\operatorname{ER} \beta$ rate $\geq 1 \%$ was defined as $\operatorname{ER} \beta$ positive $[\operatorname{ER} \beta(+)]$.

Statistical analysis. SPSS statistical software, version 17.0 (SPSS, Inc., Chicago, IL, USA) was used to analyze the data.
Differences between groups were compared using the $\chi^{2}$ test. The Kaplan-Meier method was used for survival analysis, while the log-rank test was performed to compare the differences in the survival rates. All statistical tests were two-sided, and $\mathrm{P}<0.05$ was considered to indicate a statistically significant difference.

\section{Results}

Expression levels of ER $\beta$ in breast cancer tissues. Immunohistochemical analysis was performed to determine the levels of ER $\beta$ expression in the breast cancer tissue samples. Representative immunohistochemical staining results are presented in Fig. 1. Cells with brown particles in the nucleus were considered to be ER $\beta$-positive. In the negative control group, no cells exhibited positive staining (Fig. 1A). Cells exhibiting positive ER $\beta$ staining are shown in Fig. 1B.

Rate of positive ER $\beta$ expression is reduced in patients with triple-negative breast cancer. Among the study population, 101/234 cases of breast cancer exhibited positive expression of $\operatorname{ER} \beta$ (Table I); thus, the positive expression rate was $43.2 \%$. With regard to the triple-negative breast cancer patients, 38/107 (35.5\%) cases exhibited positive ER $\beta$ expression. Furthermore, among the triple-positive breast cancer patients, positive ER $\beta$ expression was observed in 63/127 (49.6\%) cases. Statistically, the triple-negative breast cancer patients exhibited significantly lower expression levels of ER $\beta$ compared with the triple-positive breast cancer patients $\left(\chi^{2}=4.701\right.$, $\mathrm{P}=0.03)$.

Triple-negative breast cancer patients with positive ER $\beta$ expression exhibit reduced survival times. Survival analysis was performed using the Kaplan-Meier method in order to investigate the association between $\operatorname{ER} \beta$ expression and survival times in the triple-negative breast cancer patients. The Kaplan-Meier survival curve is shown in Fig. 2. The survival rate of the triple-negative breast cancer patients with negative ER $\beta$ expression was higher compared with the triple-negative patients with positive ER $\beta$ expression, and the difference was statistically significant $\left(\chi^{2}=5.330, \mathrm{P}<0.05\right)$. In addition, at the end of the follow-up period, the average DFS time for the triple-negative breast cancer patients with negative ER $\beta$ expression was 10.620 years, which was significantly higher compared with the triple-negative breast cancer patients with positive ER $\beta$ expression (7.417 years; $\mathrm{P}<0.05)$. Thus, the prognosis of triple-negative breast cancer patients with positive ER $\beta$ expression was comparatively poor.

Survival rate of patients with triple-positive breast cancer is not affected by ER $\beta$ expression. Survival analysis was also conducted to determine the association between ER $\beta$ expression and the survival rate in triple-positive breast cancer patients. The Kaplan-Meier survival curve for these patients is presented in Fig. 3. The expression of ER $\beta$ was demonstrated to exert no effect on the survival times of the triple-positive breast cancer patients. No statistically significant difference was observed in the survival rate between the triple-positive breast cancer patients with negative ER $\beta$ expression and those with positive $\operatorname{ER} \beta$ expression $\left(\chi^{2}=0.446, \mathrm{P}>0.05\right)$. Therefore, 
Table I. Expression of ER $\beta$ in patients with triple-negative and triple-positive breast cancer.

\begin{tabular}{lccc}
\hline Patients & ER $\beta$ positive, $n(\%)$ & ER $\beta$ negative, $n(\%)$ & Total $(\mathrm{n})$ \\
\hline Triple-positive & $63(49.6)$ & $64(50.4)$ & 127 \\
Triple-negative & $38(35.5)$ & $69(64.5)$ & 107 \\
Total & $101(43.2)$ & $133(56.8)$ & 234 \\
\hline
\end{tabular}

$\chi^{2}=4.701$ and $\mathrm{P}=0.030 . \mathrm{ER} \beta$, estrogen receptor $\beta$.

A

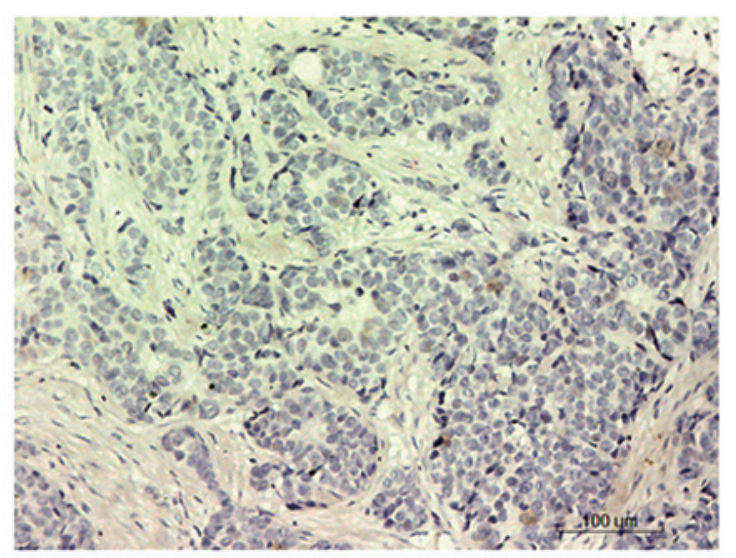

B

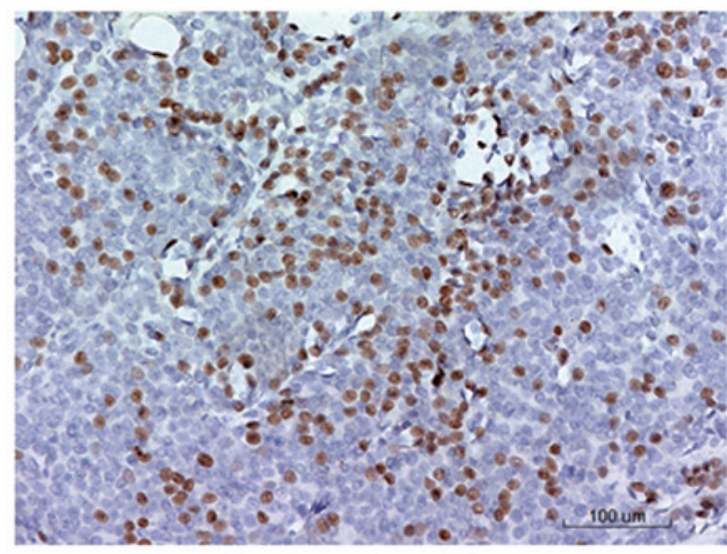

Figure 1. Expression analysis of estrogen receptor $\beta$ (ER $\beta)$ in breast cancer tissue. Immunohistochemistry was used to detect ER $\beta$ expression and representative results are presented (scale bar, $100 \mu \mathrm{m}$ ). Cells with brown particles in the nucleus were considered to be ER $\beta$-positive. (A) Negative control without ER $\beta$ expression and (B) cells with positive ER $\beta$ expression.

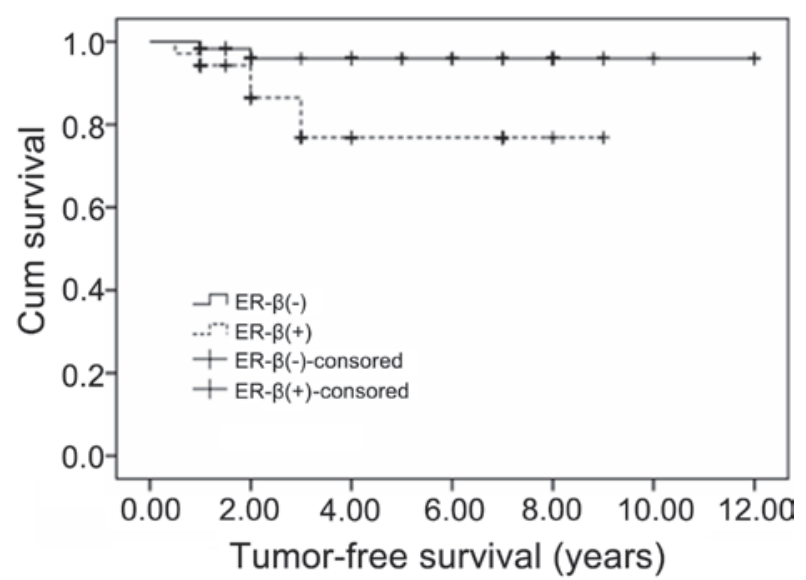

Figure 2. Kaplan-Meier survival curve showing the cumulative survival rates of triple-negative breast cancer patients with positive and negative ER $\beta$ expression. Patients that succumbed to other causes, were lost to follow-up at the time of last contact or before the study cut-off were excluded. ER $\beta$, estrogen receptor $\beta ; \operatorname{ER} \beta(-)$, negative $\operatorname{ER} \beta$ expression; $\operatorname{ER} \beta(+)$, positive $\operatorname{ER} \beta$ expression.

the prognosis of triple-positive breast cancer patients was not found to be associated with ER $\beta$ expression.

\section{Discussion}

Triple-negative and triple-positive forms of breast cancer are specific molecular subtypes of the disease of which the triple-negative breast cancer subtype is more malignant. Triple-negative breast cancer is associated with an increased

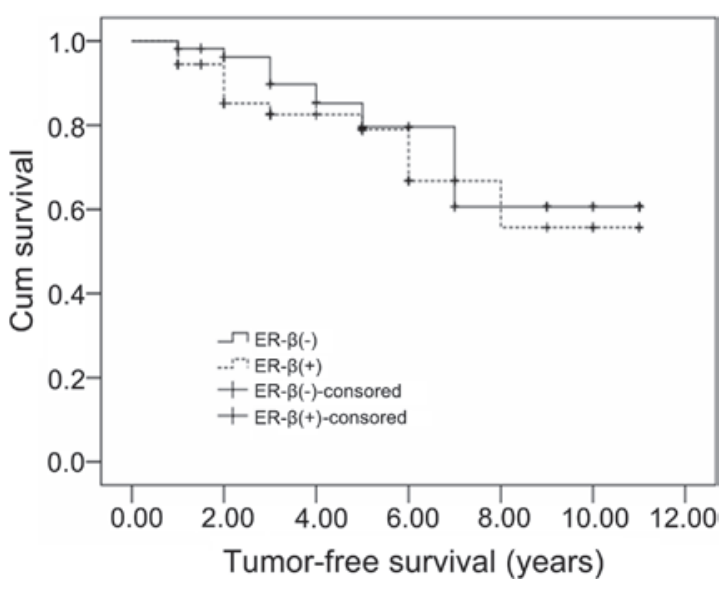

Figure 3. Kaplan-Meier survival curve showing the cumulative survival rates of triple-positive breast cancer patients with positive and negative ER $\beta$ expression. Patients that succumbed to other causes, were lost to follow-up at the time of last contact or before the study cut-off were excluded. ER $\beta$, estrogen receptor $\beta$; $\operatorname{ER} \beta(-), E R \beta$ negative expression; $\operatorname{ER} \beta(+), \operatorname{ER} \beta$ positive expression.

rate of malignancy due to the higher rates of local recurrence and visceral metastasis $(11,12)$. The ER belongs to the nuclear receptor superfamily (8). The expression of the ER subtype, $\mathrm{ER} \alpha$, in breast cancer is associated with tumorigenesis and prognosis evaluation in breast cancer (9). In addition to ER $\alpha$, an additional primary ER subtype is ER $\beta$. A previous study indicated that $E R \beta$ expression is reduced in ductal carcinoma in situ and invasive ductal carcinoma, which suggests that ER $\beta$ expression may be associated with tumorigenesis and the 
degree of malignancy of breast cancer (13). Furthermore, a prior study indicated that the expression of ER $\beta$ is unaffected by ER $\alpha$ expression (14).

In the present study, positive ER $\beta$ expression was identified in 38/107 (35.5\%) cases of triple-negative breast cancer. By contrast, among the triple-positive breast cancer patients, $63 / 127(49.6 \%)$ cases were identified to express ER $\beta$. These results demonstrate that the rate of positive ER $\beta$ expression in triple-negative breast cancer patients is significantly decreased when compared with triple-positive breast cancer patients $(\mathrm{P}<0.05)$.

Triple-negative breast cancer reportedly accounts for $10-17 \%$ of all cases of breast cancer (15). At present, the function of ER $\beta$ in the prognosis of breast cancer is contested $(15,16)$. In addition, there are few studies that have investigated the association between the expression of ER $\beta$ and the prognosis of patients with triple-negative breast cancer. In the present study, the survival analysis indicated that there was no statistically significant difference in the DFS time between the triple-positive breast cancer patients with positive ER $\beta$ expression and those with negative ER $\beta$ expression. This result suggests that the expression of ER $\beta$ may not be a relevant prognostic factor for triple-positive breast cancer patients. However, with regard to the triple-negative breast cancer patients, those who exhibited positive ER $\beta$ expression had significantly reduced DFS times when compared with those with negative ER $\beta$ expression $(P=0.021)$. This observation indicates that $\mathrm{ER} \beta$ expression may predict a poor prognostic outcome for patients with triple-negative breast cancer. Previous studies demonstrated that ER $\beta$ serves a crucial function in the regulation of tumor angiogenesis, cell proliferation and lymphatic metastasis in breast cancer (17-19). Jensen et al (20) detected the expression of ER $\beta$ and tumor proliferation markers in breast cancer tissue using immunohistochemistry. The authors observed that the expression of the tumor proliferation markers was associated with the expression of ER $\beta$, indicating that $E R \beta$ expression is correlated with high proliferative activity of tumor cells. This finding further indicates that $\mathrm{ER} \beta$ is a poor prognosis factor for breast cancer. However, the role of ER $\beta$ as an indicator of poor prognosis in patients with triple-negative breast cancer requires further investigation.

In summary, ER $\beta$ expression levels in patients with triple-negative breast cancer were lower compared with those in patients with triple-positive breast cancer. The DFS time was significantly reduced in the ER $\beta$-positive patients with triple-negative breast cancer, as compared with the ER $\beta$-negative patients. Thus, positive ER $\beta$ expression in triple-negative breast cancer patients may indicate a poor prognosis. Therefore, ER $\beta$ may be useful as a novel prognostic indicator for patients with triple-negative breast cancer. However, further studies investigating ER $\beta$ expression are required to improve understanding of the progression of triple-negative breast cancer and to aid the development of effective targets for the treatment of this disease.

\section{Acknowledgements}

This study was supported by grants from the Natural Science Foundation of Xinjiang Uygur Autonomous Region (no. 2011211A069) and the National Clinical Key Subject General Surgery Construction Project.

\section{References}

1. Bauer KR, Brown M, Cress RD, Parise CA and Caggiano V: Descriptive analysis of estrogen receptor (ER)-negative, progesterone receptor (PR)-negative, and HER2-negative invasive breast cancer, the so-called triple-negative phenotype: A population-based study from the California cancer Registry. Cancer 109: 1721-1728, 2007.

2. Arpino G, Weiss H, Lee AV, Schiff R, De Placido S, Osborne CK and Elledge RM: Estrogen receptor-positive, progesterone receptor-negative breast cancer: Association with growth factor receptor expression and tamoxifen resistance. J Natl Cancer Inst 97: 1254-1261, 2005.

3. Shi X, Lin XY, Huang Y, Zhang ZF, Wang RX and Zeng WC: Expressions of ER, PR, Her-2 in breast cancer. Zhong Liu Yan Jiu Yu Lin Chuang 21: 461-462,465, 2009 (In Chinese).

4. Kuiper GG, Enmark E, Pelto-Huikko M, Nilsson S and Gustafsson JA: Cloning of a novel receptor expressed in rat prostate and ovary. Proc Natl Acad Sci USA 93: 5925-5930, 1996.

5. Chang HG, Kim SJ, Chung KW, Noh DY, Kwon Y, Lee ES and Kang HS: Tamoxifen-resistant breast cancers show less frequent methylation of the estrogen receptor $\beta$ but not the estrogen receptor $\alpha$ gene. J Mol Med (Berl) 83: 132-139, 2005.

6. Cappelletti V, Celio L, Bajetta E, Allevi A, Longarini R, Miodini P, Villa R, et al: Prospective evaluation of estrogen receptor- $\beta$ in predicting response to neoadjuvant antiestrogen therapy in elderly breast cancer patients. Endocr Relat Cancer 11: 761-770, 2004.

7. Esslimani-Sahla M, Kramar A, Simony-Lafontaine J, Warner M, Gustafsson JA and Rochefort H: Increased estrogen receptor betacx expression during mammary carcinogenesis. Clin Cancer Res 11: 3170-3174, 2005.

8. Thomas $\mathrm{C}$ and Gustafsson JA: The different roles of ER subtypes in cancer biology and therapy. Nat Rev Cancer 11: 597-608, 2011

9. Yager JD and Davidson NE: Estrogen carcinogenesis in breast cancer. N Engl J Med 354: 270-282, 2006.

10. Dotzlaw H, Leygue E, Watson PH and Murphy LC: Expression of estrogen receptor- $\beta$ in human breast tumors. J Clin Endocrinol Metab 82: 2371-2374, 1997.

11. Young SR, Pilarski RT, Donenberg T, Shapiro C, Hammond LS, Miller J, Brooks KA, Cohen S, Tenenholz B, Desai D, et al: The prevalence of BRCA1 mutations among young women with triple-negative breast cancer. BMC Cancer 9: 86, 2009.

12. Dent R, Hanna WM, Trudeau M, Rawlinson E, Sun P and Narod SA: Pattern of metastatic spread in triple-negative breast cancer. Breast Cancer Res Treat 115: 423-428, 2009.

13. Sengupta S, Sharma CG and Jordan VC: Estrogen regulation of $\mathrm{X}$-box binding protein-1 and its role in estrogen induced growth of breast and endometrial cancer cells. Horm Mol Biol Clin Investig 2: 235-243, 2010.

14. Speirs V, Adams IP, Walton DS and Atkin SL: Identification of wild-type and exon 5 deletion variants of estrogen receptor beta in normal human mammary gland. J Clin Endocrinol Metab 85: 1601-1605, 2000.

15. Reis-Filho JS and Tutt AN: Triple negative tumours: A critical review. Histopathology 52: 108-118, 2008.

16. Vinayagam R, Sibson DR, Holcombe C, Aachi V and Davies MP: Association of oestrogen receptor beta 2 (ER beta 2/ER beta cx) with outcome of adjuvant endocrine treatment for primary breast cancer - a retrospective study. BMC Cancer 7: 131, 2007.

17. Järvinen TA, Pelto-Huikko M, Holli K and Isola J: Estrogen receptor $\beta$ is coexpressed with $\mathrm{ER} \alpha$ and $\mathrm{PR}$ and associated with nodal status, grade, and proliferation rate in breast cancer. Am J Pathol 156: 29-35, 2000.

18. Hou YF, Yuan ST, Li HC, Wu J, Lu JS, Liu G, Lu LJ, Shen ZZ, Ding J and Shao ZM: ER $\beta$ exerts multiple stimulative effects on human breast carcinoma cells. Oncogene 23: 5799-5806, 2004.

19. Knowlden JM, Gee JM, Robertson JF, Ellis IO and Nicholson RI: A possible divergent role for the oestrogen receptor $\alpha$ and $\beta$ subtypes in clinical breast cancer. Int J Cancer 89: 209-212, 2000.

20. Jensen EV, Cheng G, Palmieri C, Saji S, Mäkelä S, Van Noorden S, Wahlström T, Warner M, Coombes RC and Gustafsson JA: Estrogen receptors and proliferation markers in primary and recurrent breast cancer. Proc Natl Acad Sci USA 98: 15197-15202, 2001. 